\title{
Environmental and genetic components of variation in sexual allocation by an epialgal bryozoan
}

\author{
E. Hunter ${ }^{1}$, R. N. Hughes ${ }^{2}$ \\ ${ }^{1}$ Fusetani Biofouling Project, ERATO, JRDC, c/o Yokohama R\&D Center, Niigata Engineering Co. Ltd, \\ 27 Shin-isogo-cho, Isogo-ku, Yokohama 235, Japan \\ ${ }^{2}$ School of Biological Sciences, University of Wales, Bangor, Gwynedd LL57 2UW, United Kingdom
}

\begin{abstract}
Celleporella hyalina colonies growing on Fucus serratus were collected from the field and induced to release larvae in the laboratory. From these larvae, colonies were established on glass slides and each cloned by fragmentation. Growth and sexual activity of genotypic replicates in each of 4 environments were monitored for $12 \mathrm{wk}$. The environments, representing seasonal contrasts in the field, were created from the 4 combinations of lower/higher temperature and lower/higher food supply. Growth, measured as the production of basal autozooids (responsible for feeding), and sexual activity, measured separately as the production of basal male, frontal male and female zooids, were significantly affected by genotype and environment. Genotypes differed in colonial growth rate and in the numbers of male and female zooids produced per colony. Within genotypes, growth was fastest at higher temperature and food supply. Higher food supply encouraged the production of autozooids and sexual zooids. Higher temperature strongly encouraged female production, but not male. Male production was greatest at higher food supply combined with lower temperature, when female production was very low. Colonies maturing in 'summer' conditions therefore invested heavily in females whereas those maturing in 'winter' conditions invested heavily in males. This phenotypic response might promote fitness by ensuring that quantities of females are not produced under environmental conditions that would prolong embryogenesis and brooding beyond a critical time limit set by risks of colonial mortality. On the other hand, overlapping generations and sperm storage would provide opportunity for cross fertilization even during winter, when it would pay to invest in males. The genetically based component of variation in sexual allocation in C. hyalina may reflect polymorphism sustained by varying mating opportunities
\end{abstract}

KEY WORDS: Celleporella hyalina Simultaneous hermaphrodite $\cdot$ Clones $\cdot$ Sex allocation $\cdot$ Temperature Food

\section{INTRODUCTION}

Life-history traits, including the allocation of resources to somatic, male and female functions, show rich, natural variation (Stearns 1992). Theory predicts phenotypic adjustment of allocation to particular circumstances encountered by individuals and genetic adjustment to more general circumstances encountered by generations (Sibly \& Calow 1986). It is, therefore, necessesary to partition the phenotypic and genetic components in order to understand observed patterns of variation in life-history traits. For organisms such as most insects and vertebrates that can be propagated only by sexual reproduction, efficient partitioning of phenotypic and genetic components of variation requires protracted breeding programmes (Falconer 1989). Effective partitioning, at less expense, can be achieved when clonal propagation is possible. In this case, the response of each genotype sampled and replicated from within 1, sexually produced, generation can be measured over a range of environmental conditions (Stearns 1992). This methodology is readily 
applicable to aquatic, colonial invertebrates which, because of their modularity (sensu Harper 1977), can be propagated by division and continually monitored for their allocation to somatic or reproductive functions simply by counting the modules (Hughes 1989). We used this protocol to assess phenotypically and genetically based variation in sexual allocation within a population of the cheilostome bryozoan, Celleporella hyalina (L.).

Celleporella hyalina is an encrusting bryozoan that in British waters typically lives on the fronds of the kelp Laminaria saccharina or of the fucoid Fucus serratus (Cancino 1986). It exhibits complete modular partitioning of feeding, male and female functions (Cancino \& Hughes 1988j. Colonies are comprised of a basal layer of feeding autozooids, from which easily distinguishable male and female zooids are budded frontally, forming a second layer on top of the colony. Also, large numbers of males are formed in the basal layer by distal budding (basal males) and a few feeding zooids in the top layer by frontal budding (frontal autozooids). The sexual zooids are incapable of feeding. Counts of zooidal morphs thus serve to estimate relative investment into somatic, male and female functions (Hughes \& Cancino 1985)

Sexual allocation in Celleporella hyalina varies inter-colonially and seasonally (Cancino \& Hughes 1987). Using cloned replicates in the field D. J. Hughes (1992) produced some evidence of a genotypic component to this variation, but uncontrollable variables confounded partitioning from environmental effects. We therefore repeated the experiment in the laboratory, with accurately controlled environmental conditions chosen to simulate seasonal contrasts in factors thought to have major influences on colonial growth and sexual allocation. We interpret the phenotypic component of variation in sexual allocation as an adaptive response to seasonai conditions and discuss the genetic component in relation to mating opportunities.

\section{MATERIALS AND METHODS}

Celleporella hyalina colonies, attached to microscope slides, were cultured in the laboratory at $18^{\circ} \mathrm{C}$ on a diet of Rhodomonas baltica (Karsten) using the methods described in Hunter \& Hughes (1993a). Having grown to a size of 10 to $15 \mathrm{~mm}^{2}$, each colony was divided into 4 using a hand-held, diamond-pointed cutter to make the planes of fracture pass through the bryozoan colony. Chips bearing the quartered colonies were then glued onto a second microscope slide $(76 \times 39 \mathrm{~mm})$ using silicone sealant, with 2 genotypes per slide. On being returned to the culture tanks, the divided colonies were allowed to regener- ate until they had grown down onto the second glass surface. In each case, the glass chip bearing the original colonial fragment was then scraped away along with any extraneous silicone sealant, and the remaining colony reduced to $<8$ feeding autozooids, all sexual zooids being carefully removed. In this attempt to standardize the condition of propagules a small cluster of autozooids was left on a flat, uniform surface. Slides bearing the newly formed colonies were stacked in plastic, histological staining racks and transferred to experimental tanks where they were subjected to contrasted environmental conditions. Colonies were spaced at least $30 \mathrm{~mm}$ apart, within or between slides, in order to eliminate the interaction of feeding currents (Okamura 1988).

Temperature and food supply were chosen as physiologically relevant environmental variables that could be controlled with precision; food quality and quantity already having been shown to significantly affect colonial growth in the laboratory (Hunter \& Hughes 1993b).

Two extremes of temperature and of food supply, chosen to represent seasonal contrasts, were tested for their relative effects on measures of somatic growth and sexual allocation. All 4 combinations of temperature and food supply, hereafter referred to as 'environments' (Table 1), were used so that indepedent and interactive effects of the 2 factors could be assessed (but see below for statistical limitations). Since all colonies previously had been maintained at $18^{\circ} \mathrm{C}$, those destined for the lower-temperature environments were taken down gradually to $8^{\circ} \mathrm{C}$ over a period of $1 \mathrm{wk}$ in order to avoid temperature-shock reactions. It was assumed that fine-scale, microenvironmental variation at the level of the glass slide was insignificant, but as a precaution, slides were rotated in position when the algal suspension was replaced thrice weekly (Hunter \& Hughes 1993a). The number of colonies we could propagate and process within the time available was limited. On the one hand, however, a relatively large number of genotypes was desirable to increase the chance of contrasts being represented. On the other hand, a relatively large number of replicates was desirable to gauge intragenotypic variation within treatments. A compromise

Table 1. Specifications of the 4 experimental environments used to investigate colonial growth and sexual allocation in Celleporella hyalina. 'Cells' are of the alga Rhodomonas baltica

\begin{tabular}{|crr|}
\hline $\mathrm{E} 1$ & $8^{\circ} \mathrm{C}$ & 10 cells $\mu \mathrm{l}^{-1}$ \\
$\mathrm{E} 2$ & $8^{\circ} \mathrm{C}$ & 100 cells $\mu \mathrm{l}^{-1}$ \\
$\mathrm{E} 3$ & $18^{\circ} \mathrm{C}$ & 10 cells $\mu \mathrm{l}^{-1}$ \\
$\mathrm{E} 4$ & $18^{\circ} \mathrm{C}$ & 100 cells $\mu \mathrm{l}^{-1}$ \\
\hline
\end{tabular}


was reached as follows. Twenty-six genotypes, each derived from a sexually produced larva settled in October 1989 (methodology in Hunter \& Hughes 1993b), were represented by 1 colony per environment. An extra, relatively fast-growing genotype was propagated into 24 daughter colonies. Six of these clonemates were placed in each environment, along with the 26 non-clonemates. All colonies therefore received identical treatment and were measured in the same ways, as follows.

At weekly intervals, colonies were drawn with the aid of a camera lucida and counts were made of basal autozooids, frontal autozooids, basal males, frontal males and females. The experiment ran for $12 \mathrm{wk}$, after which time it became impossible to accurately count the zooids of the largest colonies and, moreover, colonies began to fragment through localized dieback

Somatic allocation was scored as the final numbers of basal and frontal autozooids produced, the first also being taken as the measure of colony size at the end of the experiment. Sexual allocation was scored as the ratio of the final number of sexual zooids to the number of basal plus frontal autozooids. Gender allocation was scored similarly, but separately for male and female zooids. Other ecologically important parameters, including colonial age and size when producing the first males and females, are considered elsewhere (Hunter 1991, Hunter \& Hughes 1995).

Relationships between allocation and the 2 environmental factors, Temperature and Food, were examined by Generalized Linear Model (GLM, Minitab 1985). Temperature, Food and Genotype were treated as fixed, crossed factors. As genotypes were unreplicated within environments, Temperature and Food were tested against Temperature $\times$ Genotype and Food $x$ Genotype respectively. Temperature $\times$ Food was unreplicated and so could not be tested for significance. Temperature $\times$ Food $\times$ Genotype was equated to residual error and this was used to test the significance of Genotype $\times$ Temperature and Genotype $\times$ Food. Logarithmic transformation was used to normalize distributions and equalize variances.

In the set of different genotypes, frontal males were produced only by $57.7 \%$ of colonies and females by $50.0 \%$, the data matrices containing too many zeros to justify statistical treatment of allocation as a continuous variable. GLM analysis therefore was based on the presence/absence of frontal males and females in each colony at the end of the experiment, using a binomial error distribution, the deviance for each term being treated as $\chi^{2}$ (Genstat 1987 ).

The relative importance of factors and their interactions was further assessed from their percentage contributions to total variance or deviance.

\section{RESULTS}

\section{General patterns of colonial growth and sexual development}

The final size of individual colonies ranged from 14 to 2115 basal autozooids. When averaged across environments, there was an order-of-magnitude difference in final size between the slowest and fastest growing genotypes.

Sexual development began once a number of basal autozooids had accumulated. Basal males were the first to appear, in some cases within the first week of colonial growth. Frontal males started to appear shortly after basal males, usually about the third week, but generally were much less numerous than basal males. Female zooids were produced from the third to fourth week onwards

\section{Performance of genotypes}

The final number of basal autozooids was significantly influenced by Temperature, Food and Genotype (Table 2a). Temperature was by far the most important factor, followed by Food and the interaction between Temperature and Food (Table $3 \mathrm{a}$ ). Higher temperature combined with higher food concentration promoted the fastest colonial growth (Fig. 1). Frontal autozooids (Fig. 1) were produced by relatively few colonies and their final abundance was significantly influenced only by colonial Size (Table $2 a$ ).

Basal male allocation was significantly influenced by Size (Table 2a), the negative regression coefficients differing significantly among environments $\left(F_{3,96}=5.9, p=0.001\right)$ and being steeper at lower food concentration (Fig. 1). The effect of Food was highly significant, whereas those of Temperature and Genotype were only marginally so (Table 2a). Size accounted for $56.7 \%$ of total variance, followed by Food and the interaction between Temperature and Food (Table 3a). Allocation was far greater when higher food concentration coincided with lower temperature (Fig. 1).

The number of colonies producing frontal males was significantly influenced by Food, Genotype and Temperature $\times$ Genotype (Table 2a). Food accounted for $71.6 \%$ and Temperature $\times$ Food $10.7 \%$ of total variance (Table 3a). More colonies bore frontal males at higher food concentration, but only 7 produced frontal males when lower food concentration coincided with higher temperature (Fig. 1). Frontal male production was the only measure of performance in which a genotype/environment interaction accounted for more variance than genotype itself (Table 3a) 
Table 2. Celleporella hyalina. Probabilities of $F$-ratios $\left[\chi^{2}\right.$ in last 2 columns of (a)] for the experimental factors Temperature, Food, their interactions and, where appropriate, the covariate colonial Size. Dashes signify interactions that could not be quantified because the failure of many colonies to produce frontal autozooids generated an excessively unbalanced data set. Numerical entries are regarded as marginally significant $(p<0.1)$. $\cdots p<0.001, \cdots p<0.01, \cdot p<0.05$, ns non-significant. $T \times G, F \times G$ : interaction terms for Temperature or Food and Genotype

\begin{tabular}{|c|c|c|c|c|c|}
\hline \multirow[t]{2}{*}{ (a) Genotypes } & \multirow{2}{*}{$\begin{array}{c}\text { Basal } \\
\text { autozooids }\end{array}$} & \multirow{2}{*}{$\begin{array}{c}\text { Frontal } \\
\text { autozooids }\end{array}$} & \multirow{2}{*}{$\begin{array}{l}\text { Allocation to } \\
\text { basal males }\end{array}$} & \multicolumn{2}{|c|}{ No of colonies producing: } \\
\hline & & & & Frontal males & Females \\
\hline Size & & $\cdots$ & $\cdots$ & & \\
\hline Temperature & $\cdots$ & ns & 0.082 & ns & $\cdots$ \\
\hline Food & $\cdots$ & ns & $\cdots$ & $\cdots$ & 0.075 \\
\hline Genotype & $\cdots$ & ns & 0.053 & $\because$ & $\cdots$ \\
\hline$T \times G$ & ns & - & ns & $\cdots$ & ns \\
\hline$F \times G$ & ns & - & ns & ns & 0.085 \\
\hline (b) Replicates & $\begin{array}{c}\text { Basal } \\
\text { autozooids }\end{array}$ & $\begin{array}{c}\text { Frontal } \\
\text { autozooids }\end{array}$ & $\begin{array}{l}\text { Allocation to } \\
\text { basal males }\end{array}$ & $\begin{array}{l}\text { Allocation to } \\
\text { frontal males }\end{array}$ & $\begin{array}{c}\text { Allocation to } \\
\text { females }\end{array}$ \\
\hline Size & & $\cdots$ & ns & 0.054 & $\cdots$ \\
\hline Temperature & $\cdots$ & $\because$ & $\cdots$ & $\because$ & ns \\
\hline Food & 0.055 & $\cdots$ & $\cdots$ & 0.054 & ns \\
\hline
\end{tabular}

\section{autozooids}
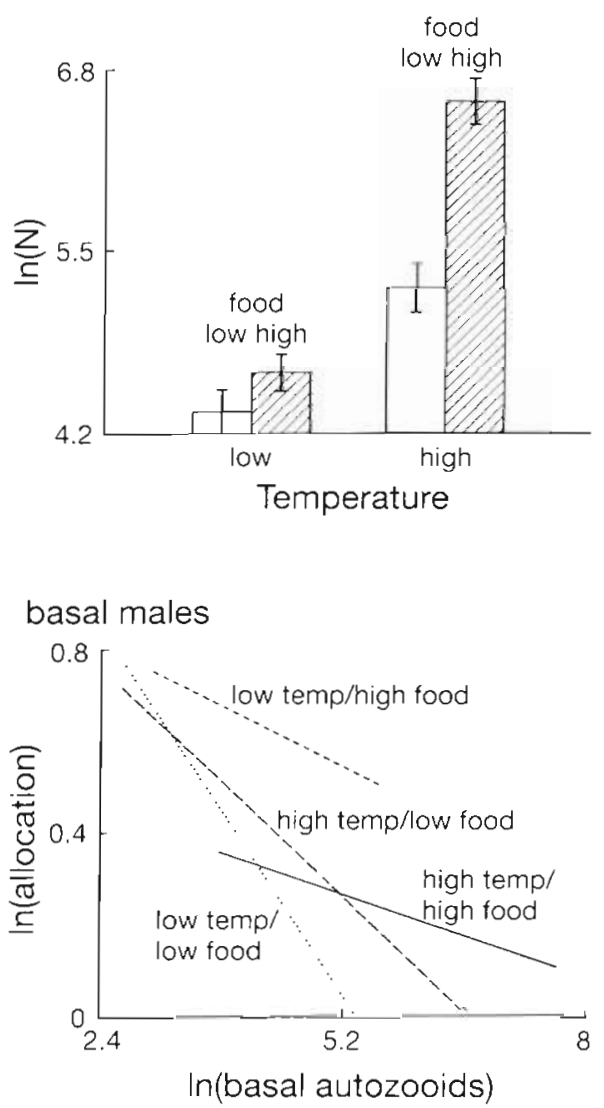

frontal autozooids
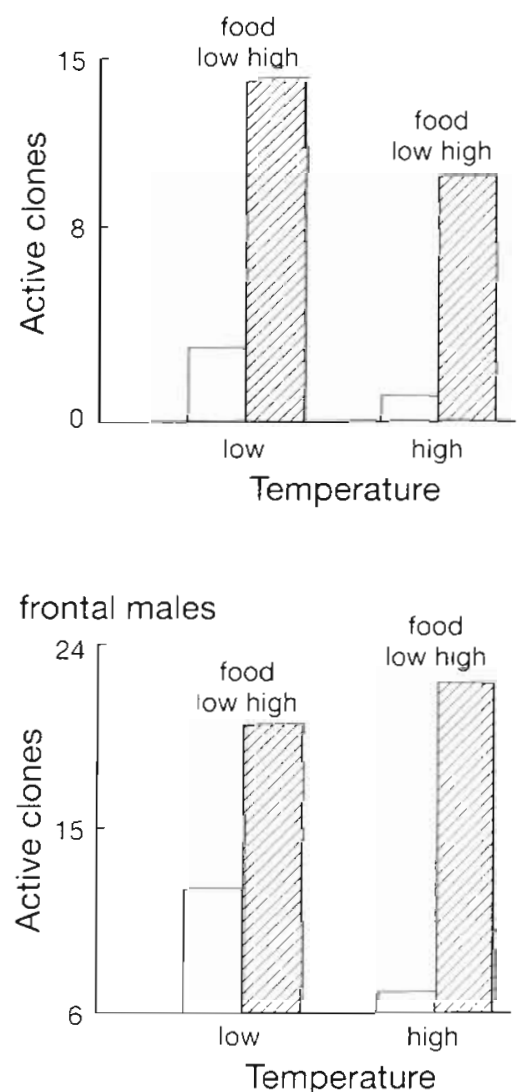

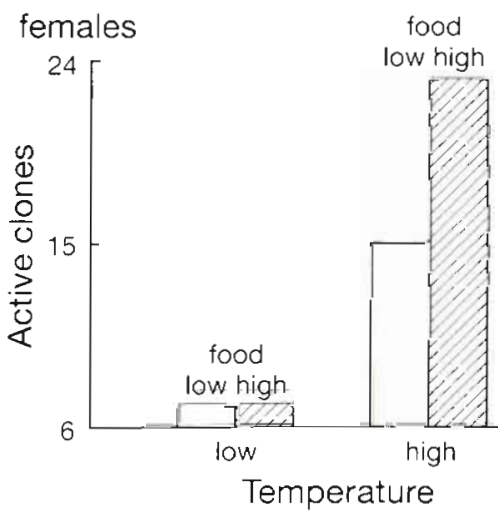

Fig. 1 Celleporella hyalina. Clonal performance. Each bar represents one of the 4 environments listed in Table 1. N: final number of basal autozooids per colony; 'active clones' number of clones producing specific zooidal types; 'allocation' (basal male zooids)/(basal+frontal autozooids). For basal autozooids, unadjusted means are presented with standard errors. Colony size was a significant covariate with frontal autozooids and basal males. In the cases of frontal autozooids slopes were not significantly different among environments and so adjusted means are given, but in the case of basal males slopes were significantly different and therefore regression lines are displayed 
Table 3. Celleporella hyalina. Percentage of variance [deviance in last 2 columns of (a)] accounted for by the experimental factors Temperature, Food and Genotype, their interactions and, where appropriate, the covariate colonial Size. Entries in bold type signify statistically significant effects (see Table 2). Dashes signify interactions that could not be quantified because failure of many colonies to produce frontal autozooids generated an excessively unbalanced data set

\begin{tabular}{|c|c|c|c|c|c|}
\hline \multirow[t]{2}{*}{ (a) Genotypes } & \multirow{2}{*}{$\begin{array}{c}\text { Basal } \\
\text { autozooids }\end{array}$} & \multirow{2}{*}{$\begin{array}{c}\text { Frontal } \\
\text { autozooids }\end{array}$} & \multirow{2}{*}{$\begin{array}{l}\text { Allocation to } \\
\text { basal males }\end{array}$} & \multicolumn{2}{|c|}{ No of colonies producing: } \\
\hline & & & & Frontal males & Females \\
\hline Size & & 86.4 & 56.7 & & \\
\hline Temperature & 65.7 & 0.2 & 1.4 & 0.6 & 67.4 \\
\hline Food & 21.7 & 6.4 & 32.7 & 71.6 & 9.3 \\
\hline$T \times F$ & 9.3 & - & 6.5 & 10.7 & 9.9 \\
\hline Genotype & 2.0 & 4.0 & 1.2 & 6.7 & 7.1 \\
\hline$T \times G$ & 0.5 & - & 0.4 & 8.7 & 2.2 \\
\hline $\mathrm{F} \times \mathrm{G}$ & 0.4 & - & 0.5 & 1.7 & 4.1 \\
\hline Error & 0.4 & 3.0 & 0.6 & 0.0 & 0.0 \\
\hline (b) Replicates & $\begin{array}{c}\text { Basal } \\
\text { autozooids }\end{array}$ & $\begin{array}{l}\text { Frontal } \\
\text { autozooids }\end{array}$ & $\begin{array}{l}\text { Allocation to } \\
\text { basal males }\end{array}$ & $\begin{array}{l}\text { Allocation to } \\
\text { frontal males }\end{array}$ & $\begin{array}{l}\text { Allocation to } \\
\text { females }\end{array}$ \\
\hline Size & & 23.9 & 0.4 & 21.0 & 87.7 \\
\hline Temperature & 86.4 & 15.9 & 4.2 & 43.2 & 1.2 \\
\hline Food & 2.0 & 50.0 & 67.5 & 21.0 & 4.6 \\
\hline $\mathrm{T} \times \mathrm{F}$ & 11.1 & 8.6 & 27.7 & 9.8 & 0.1 \\
\hline Error & 0.5 & 1.6 & 0.2 & 5.0 & 6.4 \\
\hline
\end{tabular}

The number of colonies producing females was highly significantly influenced by Temperature and Genotype and marginally significantly by Food and Food $\times$ Genotype (Table $2 a$ ). Temperature accounted for $67.4 \%$ of total variance followed by Temperature $x$ Food at $9.9 \%$ (Table 3a). Very few colonies bore females at the lower temperature (Fig. 1). At the higher temperature, female production was strongly enhanced by higher food concentration.

\section{Performance of replicates}

The final number of basal autozooids was highly significantly influenced by Temperature and marginally so by Food (Table 2b). Temperature accounted for $86.4 \%$ of total variance, followed by Temperature $x$ Food at $11.1 \%$ (Table $3 \mathrm{~b}$ ). Higher temperature promoted faster growth, particularly when in combination with higher food concentration. The final number of frontal autozooids was significantly influenced by Size, Temperature and Food (Table 2b). Food accounted for $50.0 \%$ of total variance, followed by Size, Temperature, then Temperature $\times$ Food (Table 3b). More frontal autozooids were produced by larger colonies and at higher food concentration, particularly when also at lower temperature.

Basal male allocation was significantly influenced by Temperature and Food (Table 2b). Food accounted for $67.5 \%$ of total variance, followed by Temperature $x$ Food at $27.7 \%$ (Table $3 b$ ). Allocation was high when higher food concentration coincided with lower temperature, but was minimal. in the other environments.

Frontal male allocation was significantly influenced by Temperature and marginally so by Size and Food (Table 2b). Temperature accounted for $43.2 \%$ of total variance, with Size and Food each accounting for $21.0 \%$ (Table $3 \mathrm{~b}$ ). Allocation was greater in larger colonies and at higher food concentration, particularly when in combination with lower temperature.

Female allocation was significantly influenced only by Size (Table $2 b$ ), which accounted for $87.7 \%$ of total variance (Table $3 b$ ).

\section{Comparison between replicates and genotypes}

The genotype replicated within environments (Tables $2 b \& 3 b$ ) followed the same general trends in performance shown by the other genotypes (Tables 2a \& 3a). Colonial growth increased in strong response to higher temperature and in lesser extent to higher food concentration. Basal male production was much higher when higher food concentration coincided with lower temperature. Frontal male production, also, was elevated by higher food concentration. Basal male production was negatively influenced by colonial size, although significantly so only for the unreplicated genotypes. The major difference concerned the production of females. Among unreplicated genotypes, higher temperature strongly increased the incidence of female production, although 
Table 4. Celleporella hyalina. Allocation trade offs. (a) Sexual versus somatic allocation. As both variables, In (sexual zooids/autozooids) and ln (basal autozooids), were subject to sampling error, geometric-mean regression analysis was used (Ricker 1973). (b) Male versus female allocation. The relationship between numbers of male and female zooids produced was investigated by stepwise regression on logarithmically transformed data, using the number of males as the dependent variable and number of basal autozooids and female zooids as first and second dependent variables

\begin{tabular}{|c|c|c|c|c|}
\hline & Slope & $t$-ratio & df & $\mathrm{p}$ \\
\hline \multicolumn{5}{|c|}{ (a) Sexual vs somatic allocation } \\
\hline Genotypes & -0.237 & 11.10 & 102 & $<0.0001$ \\
\hline Replicates & -0.237 & 4.81 & 22 & $<0.0001$ \\
\hline \multicolumn{5}{|c|}{ (b) Male vs female allocation } \\
\hline \multicolumn{5}{|l|}{ Genotypes } \\
\hline \multicolumn{5}{|l|}{ Basal males } \\
\hline Autozooids & 0.450 & 3.36 & 101 & 0.001 \\
\hline Female & -0.001 & 0.02 & 101 & 0.984 \\
\hline \multicolumn{5}{|l|}{ Frontal males } \\
\hline Autozooids & 0.720 & 4.09 & 101 & $<0.0001$ \\
\hline Female & 0.124 & 1.27 & 101 & 0.207 \\
\hline \multicolumn{5}{|l|}{ Replicates } \\
\hline \multicolumn{5}{|l|}{ Basal males } \\
\hline Autozooids & 5.200 & 2.94 & 21 & 0.008 \\
\hline Female & -2.070 & 3.13 & 21 & 0.005 \\
\hline \multicolumn{5}{|l|}{ Frontal males } \\
\hline Autozooids & 3.500 & 3.41 & 21 & 0.003 \\
\hline Female & -1.030 & 2.63 & 21 & 0.016 \\
\hline
\end{tabular}

the highly significant effect of Genotype showed that there was substantial variation in this response. The replicated genotype produced females in all environments and allocation increased simply in proportion to colonial size.

\section{Allocation trade ofis}

Sexual versus somatic allocation. There was a highly significant, negative association between sexual allocation and final colonial size both among genotypes and replicates (Table 4a). Moreover, the replicated genotype equalled the best of the other genotypes in speed of colonial growth, but was below mid range in sexual allocation (Fig. 2). Colonies, therefore, achieved faster growth at the expense of sexual allocation.

Male versus female allocation. This trade off was examined using stepwise regression, on data pooled across environments, to assess the effect of female production on male, once the effect of colonial size had been accounted for. A significant, negative relationship between male and female production was found among colonies of the genotype replicated within environments, but not among those of the other genotypes (Table $4 \mathrm{~b}$ ). Evidence for this trade off, therefore, was equivocal.
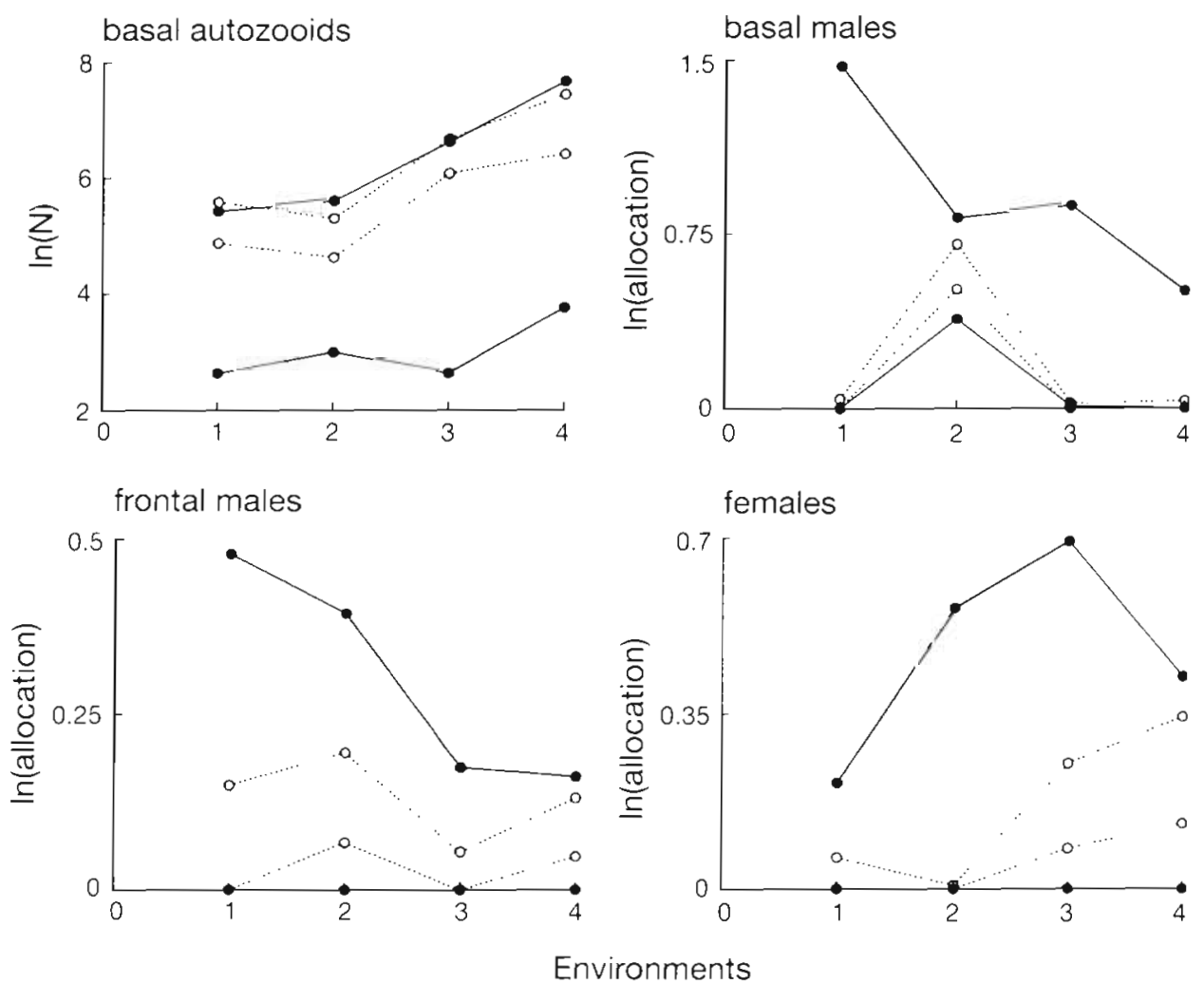

Fig. 2. Celleporella hyalina Inter- and intragenotypic variation. Maximum and minimum values of performance (defined in 'Materials and methods') are plotted across environments (defined in Table 1). Solid lines connect intergenotypic data, dotted lines intra-genotypic data 


\section{DISCUSSION}

\section{Effects of environment and genotype}

The 4 experimental environments (Table 1) presented large differences in temperature and food concentration. Temperature and Food, together with their interaction, accounted for 40.6 to $99.5 \%$ of total variance in most measures of performance (Table 3 ). This strong environmental influence probably overshadowed the effect of Genotype, which accounted for only 1.2 to $7.1 \%$ of total variance in performance (Table $3 \mathrm{a}$ ). The effect of Genotype, nevertheless, was generally significant and was most noticeably expressed in the order-of-magnitude range in mean colonial growth rate among genotypes, in the production of frontal male zooids in all environments by 4 genotypes, in the production of female zooids in all environments by 3 genotypes and of no females by 2 . Interactions between genotype and the 2 environmental factors together accounted for 0.9 to $10.4 \%$ of total variance in performance (Table 3a), but the effect was significant only in the case of Temperature $\times$ Genotype for the frequency of frontal male production and Food $\times$ Genotype for that of female production. Both instances involved the envrionmental factor having lesser importance as a main effect (Table 2a). One genotype produced frontal males only at the lower temperature and another only at the higher, while 2 genotypes produced females only at the higher food concentration.

We conclude that sex allocation in Celleporella hyalina is sensitive to environmental conditions, principally through the triggering of female production by higher temperature and the trade off in allocation to males and females, in which females have priority. We also conclude that genetically based variation in sexual allocation and in responsiveness of allocation to environmental conditions may exist within relatively small sub-populations, as with the present case taken from a patch of Fucus serratus.

\section{An ecological interpretation}

Temperature and food supply appear to be key factors controlling sexual allocation in Celleporella hyalina. In most genotypes we studied, higher temperature triggered the production of females, which took priority in allocation. Increased food supply promoted the production of all types of zooid, but this strongly affected males only at lower temperature when female production was suppressed.

At about 16 to $18^{\circ} \mathrm{C}$ the first females are formed in 3 to $4 \mathrm{wk}$ (present data), taking a further 3 to $4 \mathrm{wk}$ to mature and release larvae (Cancino \& Hughes 1988).
At lower temperature this cycle would be slower, prolonging exposure to the risks of substratum disintegration (Cancino 1986), competitive overgrowth $\left(\mathrm{O}^{\prime} \mathrm{Con}\right.$ nor et al. 1980), predation, or damage by physical factors such as storms and exposure to freezing on winter low tides. Colonies settling towards the end of the seasonal pulse of recruitment (Seed \& Hughes 1992) therefore should gain relatively little fitness by investing in females, once temperature is in decline Colonies settled somewhat earlier, however, already will have produced females and will carry them through the winter. Also, perhaps as in other taxa (Ryland \& Bishop 1993), colonies may be able to store exogenous sperm until ova are ready for fertilization Opportunities for cross fertilization therefore would persist and overwintering colonies would gain fitness by continuing to produce males.

According to this interpretation, the optimal policy is to give priority to female allocation whenever the enviroment allows generation time to be short and to allocate any remaining excess over somatic requirements to male production. Why, then, do some genotypes appear to produce females over a wide range of conditions and others scarcely at all? Similar extremes have been found among genotypes cloned and reared under more complex, field conditions (Cancino \& Hughes 1987). When experimentally forced to self fertilise, Celleporella hyalina suffers severe inbreeding depression (Hunter \& Hughes 1993c). Fitness therefore depends on the accessibility of potential mates and, in the case of male function, on competition for mates (Charnov 1982). Variation in these factors might generate shifting selection pressures that maintain polymorphic life-history traits. Much will depend on the dynamics of fertilization (Petersen 1991). The extent to which spermatozoa are mixed by turbulence (Denny \& Shibata 1989) is unknown and further work is required to characterize their movement in relation to boundary-layer flow and the inhalant currents of neighbouring colonies (Okamura 1985). We cannot, therefore, offer any firm explanation for genetically based variation in the sexual allocation of $C$. hyalina, but spatial variation in mating opportunity, interacting with seasonal changes in generation time and brooding success seem good candidates for future examination.

\section{Experimental design}

Environments. The experimental diet was unnatural in presenting colonies with only 1 food organism and this at unnaturally high concentration (Fogg \& Thake 1987). Nevertheless, previous trials (Hunter \& Hughes 1991) had shown that Rhodomonas baltica promotes far better growth when presented alone to colonies 
than when mixed with other algae commonly used in laboratory culture. Moreover, 'low' and 'high' concentrations, as used in the present study, were found to support moderate and maximal growth rates respectively. Temperatures fell within the natural range, the higher level slightly exceeding the average summer maximum sea temperature of $16^{\circ} \mathrm{C}$ and the lower exceeding the average winter minimum of $4^{\circ} \mathrm{C}$ (Cancino 1983). Colonies exposed during low tide would experience greater extremes of temperature. The 4 environments therefore embraced seasonally contrasted growth conditions: high temperature in summer, low temperature in winter and periods of high and low food supply in either season.

Genotypes. Larvae used to establish the clones were a random sample of those released by colonies attached to Fucus serratus, collected from a single locality. Experimental genotypes, however, were not randomly drawn from these larvae. The experiment began once a sufficient number of genotypes had been propagated into 4 replicates, perhaps inadvertently selecting for faster growers. This effect would have been lessened by the failure of many genotypes to regenerate in all 4 replicates, requiring the experiment to be delayed until slower-growing genotypes had become established. Thus, the order-of-magnitude difference between the slowest-and fastest-growing experimental genotypes may not have grossly underrepresented the natural range.

Error. For each measure of performance, the intragenotypic range was much less than the inter-genotypic (Fig. 2). Moreover, intra-genotypic maxima and minima varied in parallel, showing consistency in response to environment. Intra-genotypic variation, nevertheless, was considerable. Final colonial size was much smaller in 2 of the 6 replicates exposed to higher temperature and higher food concentration. This optimal environment for autozooidal production would have exaggerated any intrinsic differences in growth potential. Such differences could have several origins. The most probable is a difference in number or health of basal autozooids, accidentally inflicted when establishing the colonial fragments. Loss or damage to even 1 zooid among a small cluster of about 8 ('Methods'), although not necessarily affecting the specific growth rate, could significantly restrict the final size achieved (Seed \& Hughes 1992). Following perhaps in decreasing order of probability are cytological differences among fragments derived from different parts of the parental colony (Suzuki et al. 1986) and the occurrence, before or after fragmentation, of somatic mutations (Slatkin 1984). The origin of fragments from peripheral or central areas of the parental colony is known to influence subsequent growth in the encrusting bryozoan Mucropetraliella ellerii (Klemke 1993) and perhaps could have contributed to variation in sexual activity within environments in the present study. There is no evidence relating somatic mutation to differences in performance among clonemates in colonial invertebrates (Hughes 1989), although the application of molecular techniques may yet show this to be significant. With only 2 replicates per environmental factor, intragenotypic variation could easily masquerade as genotype-environment interaction. If such variation were caused by initial differences in fragmental size, there would be significant interaction between the final number of basal autozooids and 1 or more environmental factors. This was not the case: evidence of genotype-environment interaction was confined to measures of sexual activity uncorrelated with colonial size. Inherited cytological differences among clonemates might have influenced sexual activity, but the quartering of parental colonies ensured that each fragment was derived from a similar proportion of peripheral and central zooids, lessening the probability of this source of variation. Somatic mutation may be discounted since, had it occurred, its frequency would have been too low to generate statistically significant interaction terms.

\section{A prospectus}

We have demonstrated both phenotypic plasticity and genetic control of sex allocation in Celleporella hyalina. In the present case, variation in sex allocation was driven by combinations of food supply and ambient temperature, but other kinds of factor also could be important. For example, Cancino et al. (1991) found that colonies of $C$. hyalina grown from the larval stage in complete isolation from conspecifics failed to produce females, although they produced males in normal quantities. Opportunities for fertilization, as determined by the distribution of neighbours, therefore may influence sex allocation in this and other bryozoans (Harvell \& Grosberg 1988, Cancino et al. 1991). Because of its zooidal polymorphism and amenability to laboratory culturing, $C$. hyalina holds great promise as an experimental model for addressing questions on the evolution of life-history schedules (Stearns 1992) and mating strategies (Charnov 1982).

\section{LITERATURE CITED}

Cancino, J. M. (1983). Demography of animal modular colonies. Ph.D. thesis, University of Wales, Bangor

Cancino, J. M. (1986). Marme macroalgae as a substratum for sessile invertebrates: a study of Celleporella hyalina (Bryozoa) on fronds of Laminaria saccharina (Phaeophyta). Monographiae biol. 4: 279-308

Cancino, J. M., Castañeda, B., Orellana, M. C. (1991). Repro- 
ductive strategies in bryozoans: experimental tests of the effects of neighbours. In: Bigey, F. P. (ed.) Bryozoaires actuels et fossiles: Bryozoa living and fossil. Bull. Soc. Sci Nat. Ouest Fr. Mém. HS 1, Nantes: 81-88

Cancino, J. M., Hughes, R. N. (1987). The effect of water flow on growth and reproduction of Celleporella hyalina ( $\mathrm{L}$.) (Bryozoa: Cheilostomata). J. exp. Mar. Biol. Ecol 112 $109-130$

Cancino, J. M., Hughes, R. N. (1988). The zooidal polymorphism and astogeny of Celleporella hyalina (Bryozoa: Cheilostomata). J. Zool., Lond. 215: 167-18.1

Charnov, E. L. (1982). The theory of sex allocation. Princeton University Press, Princeton

Denny, M. W., Shibata, M. F. (1989). Consequences of surfzone turbulence for settlement and external fertilization. Am. Nat. 134:859-889

Falconer, D. S. (1989). Introduction to quantitative genetics, 3rd edn. Longman, London

Fogg, G. E., Thake, B. (1987). Algal cultures and phytoplankton ecology. University of Wisconsin Press, Madison

Genstat (1987). Genstat manual. Clarendon Press, Oxford

Harper, J. L. (1977). Population biology of plants. Academic Press, London

Harvell, C. D., Grosberg, R. K. (1988). The timing of sexual maturity in clonal animals. Ecology 69: 1855-1864

Hughes, D. J. (1992). Genotype-environment interactions and relative clonal fitness in a marine bryozoan. J. Anim. Ecol. 61: $291-306$

Hughes, R. N. (1989). A functional biology of clonal animals. Chapman \& Hall, London

Hughes, R. N., Cancino, J. M. (1985). An ecological overview of cloning in Metazoa. In: Jackson, J. B. C., Buss, L. W. R., Cook, E. (eds.) Population biology and evolution of clonal organisms. Yale University Press, New Haven, p. $153-186$

Hunter, E. (1991). Variation in growth and reproduction in a marine bryozoan. Ph.D. thesis, University of Wales, Bangor

Hunter, E., Hughes, R. N. (1991). Growth of laboratory cultured colonies of Celleporella hyalina (L.). Bull. Soc. Sci. Ouest Fr., Mem. HS 1 Nantes: 187-191

Hunter, E., Hughes, R. N. (1993a). The effect of cell concentration on colony growth and feeding in the bryozoan Celleporella hyalina. J. mar. biol. Ass. U.K. 73: 321-331

This article was submitted to the editor
Hunter, E., Hughes, R. N. (1993b). Effects of diet on lifehistory parameters of the marine bryozoan, Celleporella hyalina (L.). J. exp. mar. Biol. Ecol. 167: 163-177

Hunter, E., Hughes, R. N. (1993c). Self-fertilisation in Celleporella hyalina. Mar. Biol. 115: 495-500

Hunter, E., Hughes, R. N. (1995). Environmental and genetic control of somatic and sexual performance in Celleporella hyalina (L.). In: Gordon, D. P., Thompson, R.-M. (eds.) Bryozoans in space and time. Bull, R. Soc. N.Z. (in press)

Klemke, J E. (1993). Life history variation in the bryozoan Mucropetraliella ellerii (Macgillivray). Ph.D. thesıs, University of Melbourne

Minitab (1985). Minitab handbook. Ryan, B. F., Joiner, B. L., Ryan, T. A. (eds.) Duxbury Press, Boston

O'Connor, R. J., Seed, R., Boaden, P. J. S. (1980). Resource space partitioning by the Bryozoa of a Fucus serratus L. community. J. exp. mar. Biol. Ecol. 45: 117-137

Okamura, B. (1985) The effects of ambient flow velocity. colony size and upstream colonies on the feeding success of bryozoa. II. Conopium reticulum (Linnaeus), an encrusting species. J. exp. mar. Biol. Ecol. 89: 69-80

Okamura, B. (1988). The influence of neighbors on the feeding of an epifaunal bryozoan. J. exp. mar. Biol. Ecol. 120 105-123

Petersen, C. W. (1991). Sex allocation in hermaphroditic sea basses. Am. Nat. 138: 650-667

Ricker, W. E. (1973). Linear regression in fishery research. J. Fish. Res. Bd Can. 30: 409-434

Ryland, J S., Bishop, J. D. D. (1993). Internal fertilisation in hermaphroditic colonial invertebrates. Oceanogr mar. Biol. A. Rev. 31: 445-477

Seed, R., Hughes, R. N. (1992). Reproductive strategies of epialgal bryozoans. Invert. Reprod. Dev. 22: 291-300

Sibly, R. M., Calow, P. (1986). Physiological ecology of animals. Blackwell Scientific Publications, Oxford

Slatkin, M. (1984). Somatic mutations as an evolutionary force. In: Greenwood, P. J., Harvey, P. H., Slatkin, M. (eds.) Evolution: essays in honour of John Maynard Smith. Cambridge University Press, Cambridge, p. 19-30

Stearns, S. C. (1992). The evolution of life histories. Oxford University Press, Oxford

Suzuki, D. T., Griffiths, A. F. J., Miller, J. H., Lewontin, R. C. (1986). Introduction to genetic analysis, 3rd edn. W. H. Freeman, New York

Manuscript first received: September 23, 1994

Revised version accepted: January 23, 1995 